\title{
The Copernican Revolution in Pragmatism? Dewey on Philosophy and Science
}

Tracy Ann P. Llanera

\section{The Copernican Revolution in Philosophy}

\begin{abstract}
$A$
Copernican revolution ${ }^{1}$ heralds a grand renovation of a tradition of knowledge. In science-the discipline from which the concept originates-it aptly connotes a paradigm shift from a previously accepted notion of reality. It is upon this conceptualization that John Dewey wrote: "Kant claimed that he had effected a Copernican revolution in philosophy by treating the world and our knowledge of it from the standpoint of the knowing subject." 2 For the Enlightenment thinker, traditional philosophy construed a rational system of nature and then borrowed from it the features by which to characterize knowledge. He argued that this "borrowing" of a rational system should not be credited to some outworldy power, but to human reason. Thus, his "revolution" was a shift from theological to human authorship and a placing of the locus of intellect in man as a knowing subject. Kant's work created a new center in philosophy: that it is the mind that knows by means of an equipment of powers complete within itself and that it merely exercises its capabilities upon an antecedent external material equally complete in itself. It is in the preface of the Critique of Pure Reason where Kant suggested the viability of his epistemological method:
\end{abstract}

Hence let us once try whether we do not get farther with the problems of metaphysics by assuming that the objects must conform to our cognition, which would agree better with the requested possibility of an a priori cognition of them, which is to establish something about objects

${ }^{1}$ In the $16^{\text {th }}$ century, Nicolaus Copernicus overthrew Ptolemy's geocentric cosmology by proposing that the sun is actually at the center of the universe. His postulation of the heliocentric model is now considered as a monumental discovery that ushered medieval science to the modern period - a period characterized by the rejection of ancient and medieval ideas, and the blooming of new areas in science such as astronomy, biology, physics, chemistry, etc. The term "Copernican Revolution" is hence widely recognized as something that harks a great transformation in a field of knowledge.

2 John Dewey, The Quest for Certainty: A Study of the Relation of Knowledge and Action (New York: G.P. Putnam, 1960), 287. 


\section{THE COPERNICAN REVOLUTION IN PRAGMATISM?}

before they are given to us. This would be just like the first thoughts of Copernicus, who, when he did not make good progress in the explanation of the celestial motions if he assumed that the entire celestial host revolves around the observer, tried to see if he might not have greater success if he made the observer revolve and left the stars at rest. ${ }^{3}$

Patterned after the Copernican discovery in the natural sciences, he continued the tenability of his transformative view by proposing that it is external reality that conforms to the capacities of the mind:

Now in metaphysics we can try in a similar way regarding the intuition of objects. If intuition has to conform to the constitution of objects, then I do not see how we can know anything of them a priori; but if the object (as an object of the senses) conforms to the constitution of our faculty of intuition, then I can very well represent this possibility to myself. ${ }^{4}$

What is crucial in the statement of Kant is his justification that philosophy can be preoccupied with itself-that it can epistemologically operate on its own, as it is concerned with being the foundational research program of all knowledge possible to man. And because of the proclamation of the human mind's ability to taxonomize knowledge between the science of the categories of the mind (philosophy) and the science of the external world, the effect has been the eventual separation of theory and human action. According to Dewey, the chief cause of the split is that philosophy has assumed for its function the knowledge of reality, which makes it a rival instead of a complement to the sciences. Kant's Copernican revolution has forced philosophy into claiming a kind of knowledge which is more ultimate than all the others. ${ }^{5}$ Although Kant's contribution to the overhauling of traditional views is undeniable and his participation has deepened man's philosophical

\footnotetext{
3 Immanuel Kant, Critique of Pure Reason, trans. by Paul Guyer and Allen Wood (Cambridge University Press, 1999), 110.

${ }^{4} \mathrm{Ibid}$. Kant first proposed his critique in our way of thinking merely as a hypothesis to draw our notice to the first attempts at such a transformation, which are always hypotheticalsomething that Copernicus also experienced when he ventured to seek for the observed movements in the observer, and not in heavenly objects. In the same way that Copernicus was able to establish the central laws of motion with certainty, Kant also fully believed himself as successful in undertaking an entire revolution on metaphysics according to the example of geometers and natural scientists through his Critique of Pure Reason: "It is a treatise on the method, not a system of the science itself; but it catalogs the entire outline of the science of metaphysics, both in respect of its boundaries and its respect of its entire internal structure." Ibid., 113.

5 Ibid., 309.
} 
understanding, it has unfortunately severed the intimate connection between man as a knowing subject and as a participant in the realm of action. ${ }^{6}$

\section{Rivalry between Philosophy and Science}

Dewey is not alone in proclaiming that the friction between philosophy and science is a product of Kantian epistemology-a view of knowledge that has pervaded the tradition of philosophy and its relation with other disciplines. 7 Richard Rorty, a successor to the American pragmatist

${ }^{6}$ It is unfortunate that Kant's socio-political works have been neglected in favor of his metaphysical and epistemological writings, with the latter treated as the basis of future philosophical endeavors. But such focus on episteme is perhaps the unintended consequence of his effort in putting philosophy into a secure path of science: "Ever since philosophy became a self-conscious and professionalized discipline, around the time of Kant, philosophers have enjoyed explaining how different their subject is from such merely "first-intentional" matters as science, art, and religion. Philosophers are forever claiming to have discovered methods which are presuppositionless, or perfectly rigorous, or transcendental, or at any rate purer than those of nonphilosophers. (Or, indeed, of any philosophers save themselves and their friends and disciples.) Philosophers who betray this gnostic ideal (Kierkegaard and Dewey, for example) are often discovered not to have been 'real philosophers'." Richard Rorty, "Keeping Philosophy Pure: An Essay on Wittgenstein," in Consequences of Pragmatism (Minneapolis: University of Minnesota Press, 1982), 19. But even if this were so, one could still argue the scientism involved in Kant's writings outside his Critique of Pure Reason. His foundational notions of the "categorical imperative" and morality are based on a universally shared consciousness that distills the essence, albeit in a practical sense. Dewey even alludes to the pragmatist Peirce's understanding of Kant in the Metaphysic of Morals, where Kant's philosophy is always rooted in a collective rationality: "Following his own words, for a person "who still thought in Kantian terms most readily, 'praktisch' (rules of art and technique which are based on experience and are applicable to experience) and 'pragmatisch' (a priori moral laws) were as far apart as the two poles; the former belonging in a region of thought where no mind of the experimental type can ever make solid ground under his feet, the latter expressing relation to some definite human purpose. Now quite the most striking feature of the new theory was its recognition of an inseparable connection between rational cognition and rational purpose." John Dewey, "The Development of American Pragmatism," in The Essential Dewey, Volume 1: Pragmatism, Education, Democracy, ed. by Larry A. Hickman, and Thomas M. Alexander (Indiana University Press, 1998), 3-4. Though Kant does not explicitly mention that his works as a whole initiate a Copernican revolution in philosophy (apart from his insistent novelty in the analysis of speculative reason), one can argue that even his aesthetics and a priori moral laws are all within the realm of Reason as intuited and shared by all men.

7 This is not to say, of course, that Kant is entirely to blame; in fact, Dewey himself recognizes that historically, the terminology of philosophy has always been composed of various antithetical conceptions involved in the theory of knowing-such as the opposition between empirical and rational knowing, the distinction between the particular and the universal, knowledge as an external accumulation of cognitions and a ready-made body of truth, and the like-which are separations that have eventually culminated in an attitude of dualism between knowing and doing, theory and practice, between mind as the end and spirit of action and the body as its organ and means. John Dewey, "Theories of Knowledge in Democracy and Education (1916)," in Pragmatism: A Reader, ed. by Louis Menand (Vintage, 1997), 206-208. But even so, it can be argued that this intellectual framework has made the "Kantian revolution" a perfectly tenable direction for philosophy, as the critique on reason seems well-placed in the search for foundational knowledge. In a way, this dualistic philosophical attitude peaked with Kant's convincing contribution for it effectively severed the concern for the theoretical and the practical. 


\section{THE COPERNICAN REVOLUTION IN PRAGMATISM?}

tradition and a self-proclaimed admirer of Dewey, also blames Kant for setting his "theory of knowledge" as the foundation of the sciences. Kant managed to transform the old notion of philosophy-metaphysics as the "queen of the sciences" because of its concern with what was most universal and least material-into the notion of the "most basic discipline"-a foundational discipline. It became "primary" no longer in the sense of "highest" but in the sense of "underlying." " Philosophy relegated itself into the background of all knowledge, justifying its theoretical treatment of all things. Quite differently, Jürgen Habermas also questioned the separation, which resulted to science's emancipation from the philosophical concern of evaluation. In his seminal work Knowledge and Human Interests, he proclaimed that "Since Kant, science has no longer been seriously comprehended by philosophy." 9 Philosophy has dislodged itself from its position as regards to the objects and interests of scientific investigation; as a result, the science of external reality became free to believe only in itself. The scientific method of the natural sciences became the supreme method to obtain knowledge of the world. Hence, for these formidable thinkers, the rough divide between philosophy and science is unquestionable, and that Kant's role in this separation is monumental enough to analogize it to a Copernican revolution-for Kant has ushered the legacy that philosophy should be respected as the most formidable science.

Dewey interprets that the highly theoretical and abstract character of philosophy arose due to the strong scientific attitude of intellectuals in the Enlightenment. In fact, this characterization serves as proof that the question of its academic practice centered on this version of the question of knowledge; as such, Dewey insinuates that treating "philosophy as science" is actually a product of the historical context:

When I say that the only way out is to place the whole modern industry of epistemology in relation to the conditions which gave it birth and the function it has to fulfill, I mean that the unsatisfactory character of the entire neo-Kantian movement is in its assumption that knowledge gives birth to itself and is capable of affording its own justification. ${ }^{10}$

But even though one may treat this attitude as contingent, the preoccupation of philosophy with itself has led to its bifurcation with the

\footnotetext{
8 Richard Rorty, Philosophy and the Mirror of Nature-Thirtieth-Anniversary Edition (Princeton University Press, 2009), 132.

9 Jürgen Habermas, Knowledge and Human Interests (USA: Beacon Press, 1972), 4. White even explains that Habermas concluded that science has been treated not only as one category of possible knowledge, but it is, in fact, the epistemology itself. See Stephen White, "Reason, Modernity and Democracy," in The Cambridge Companion to Habermas (Cambridge University Press, 1995), 3-18.

${ }^{10}$ John Dewey, "The Significance of the Problem of Knowledge," in Philosophy and Civilization (New York: Capricorn Books, 1963), 19-20.
} 
concerns of the external world. Practically speaking, it is not surprising that science-specifically the application of it-is rarely directed by philosophy after it settled on its own system of inquiry due to influence of Kantian epistemology. Philosophy, with its haughty stance of claiming its foundational nature and keeping its discussion within the four walls of the academe, has largely ignored its capability of interpreting and challenging the numerous progresses of technology. It has allowed modern science to combine the objectivating attitude of the disinterested observer with the technical attitude of an intervening actor in producing experimental effects. ${ }^{11}$ The creation of bombs, the internet boom, biotechnology, and space travel are all but products of applied experimentation. However, it is unfortunate that in most of these cases, philosophers have not been at the forefront, collaborating with scientists regarding the goals of experimentation and the possible outcomes of such technologies.

Philosophy, hence, always plays a reactionary role instead of a directive one as regards to science. This is extremely dangerous, as many scientific discoveries have a large impact on the concerns of man-ethics, politics, psychology, and society-which are touchpoints of philosophical understanding. For Dewey, the need for large and generous ideas in the direction of life was never more urgent than in the confusion of tongues, beliefs and purposes that characterizes present life. ${ }^{12}$ The exigency to respond to such situation is indisputable, especially since "the progress of natural science has been ever more rapid and extensive than could have been anticipated." 13 Such reality is even made more dangerous by the presence of the ideology that science is completely neutral and indifferent as to the ends and values which move men to act: that at most, it only provides more efficient means for realization of ends that are and must be due to wants and desires completely independent of science. ${ }^{14}$ The notion of an unquestioned science and the presence of ambiguous ends, values, wants and desires is hence a manifestation of philosophy's detachment to practical reality; this is lamentable, given that these are legitimate and pressing domains of philosophical concern.

The way out of this predicament is to enact a new Copernican revolution: challenging, but not necessarily dismissing, the viability of Kant's

11 Jürgen Habermas, The Future of Human Nature (Polity, 2003), 45.

12 Dewey, The Quest for Certainty, 311.

13 John Dewey, "Science and Free Culture," in The Political Writings (Cambridge: Hackett, 1993), 48. Dewey does not blame the gap between the two systems of knowledge solely on philosophy; in fact, he recognizes that the rise of political and social changes such as democracy, free trade, and economic gain have pushed science to operate on its own as well: "It is said that the principles of laissez-faire individualism have governed the conduct of scientific inquiry; that the tastes and preferences of individual investigators have been allowed to regulate its course to such an extent that present intellectual confusion and moral chaos of the world exists because of tacit connivance of science with uncontrolled individualistic activity in industry." Furthermore, "it is argued (and some who take the position are themselves scientists) that the main directions of science during the past hundred years, increasingly so in the last century, have been set, indirectly and directly, but the requirements of industry carried on for private profit." Ibid., 49-50.

${ }^{14}$ Ibid., 51. 


\section{THE COPERNICAN REVOLUTION IN PRAGMATISM?}

supposed transformation in philosophy. Since Kant happens to author the phrase "Copernican revolution" in the intellectual tradition-a powerful characterization that Dewey, in The Quest for Certainty, recognizes-his epistemology forms a convenient point of departure to consider a genuine reversal of traditional ideas about the mind, reason, conceptions, and mental processes. In this case, there is a need to propose a paradigm shift from which one can realign the relationship of the sciences of external reality and human action.

It is here that Dewey's pragmatic thought comes to the fore in forging the seemingly binary opposition of philosophy and natural science. According to Dewey, science and metaphysics, or philosophy, are really the most intimate allies. For him, what philosophy should be is the coming to consciousness of this claim of the individual to be able to discover and verify the truth for himself, and thereby not only direct his own conduct, but become an influential and decisive factor in the organization of life itself. Science, on the other hand, is the general faith or creed asserting itself in detail; it is the practical belief at work engaged in subjugating the foreign territory of ignorance and falsehood step by step. ${ }^{15}$ So threshing out a complementary relationship between science and philosophy is thus the measure of a new Copernican revolution in philosophy, and pragmatism is Dewey's answer to overhaul this tradition. ${ }^{16}$

The concern of this paper is hence to answer the question: Does Dewey's pragmatism effect a Copernican revolution in the relationship between philosophy and science?

\footnotetext{
${ }^{15}$ Dewey, Philosophy and Civilization, 14.

16 In the course of this paper, one will notice the close affinity that American pragmatism has with Critical Theory and Marxism, which both originated in Continental Europe. These traditions generally lament the divorce of philosophy from the tangible affairs of the world, and their pragmatic, critical and materialist conceptions are ways of altering the Kantian posterity of searching for a transcendental ideal. Though they diverge in many different issuesranging from the role of language to the effects of modernity-it is not surprising that contemporary dialogues ensue due to their practical interests for the future of philosophy to the point that their specific identifications are corroded. Jürgen Habermas, for example, is identified with both schools of thought, and Richard Rorty's and Hilary Putnam's writings provoke debates with continental counterparts. A work such as Debating the State of Philosophy: Habermas, Rorty, and Kolakowski edited by Jozef Niznik and John Sanders (Westport, CT: Praeger, 1996) is also not a novelty as the concerns of these thinkers are intricately connected with each other. However, this article generally focuses on pragmatism, the "chief glory of the country's intellectual tradition," that arose as a response to logical empiricism — the standard, academic, neo-Kantian, epistemologically-centered philosophy in America, and particularly on Dewey's thought in the early $20^{\text {th }}$ century, which attempted to zero in on the repercussions of the "Kantian revolution" in philosophy, its dichotomizing effects on theory and action, and the possibility way of putting the two spheres together through a scientifically-informed philosophy. Hence, Deweyan pragmatism is not antagonistic against science and in fact uses its methods to develop its philosophical outlook. See Rorty, Consequences of Pragmatism, 160.
} 


\section{Dewey's Pragmatism}

Pragmatism recognizes that "philosophy cannot disavow responsibility for many misconceptions of the nature of intelligence which now hamper its efficacious operation." 17 Dewey believes that philosophy, with the notion of superior reality, is the cause of isolation from common sense, science, and practical life. Thus, it has a negative task of rejecting the identification with problems that are supposed to depend on Reality as such, or its distinction from a world of Appearance, or its relation to a Knower as such. Pragmatism then does not develop a theory of ultimate reality that is prized apart from everyday occurrence, for it is content to proclaim that daily life and its texture of events are enough to be reckoned with. In this way, philosophy can be rendered useful only after it has divorced itself from its ephemeral concerns and allows itself to be transformed as a method in dealing with tangible and compelling problems of men.

This pragmatic role-novel as it is in the interpretation of Dewey-is still concerned with epistemology, but it is one in which knowledge is described as that which is organically developed. This means that it is never final or complete but grows in the interaction with the environment. In this regard, philosophical utility is bound with the recognition of continuity: that knowledge is a mode of participation, valuable in the degree in which it is effective. It cannot be the idle view of an unconcerned spectator. ${ }^{18}$ Man is an intimate participant in the activities of the world to which he belongs—and in this process, his experience is enriched and enlarged and consequentially raises the need for acute observation and inquiry: for when it is understood that philosophic thinking is caught up in the course of actual events, problems will undoubtedly present themselves. These true-to-life issues can be found in education, economics, politics, and applied science, which are contexts where intellectuals have to help unload the baggage of traditional philosophizing that restrict the possibilities of thinking and acting in particular situations.

So instead of mirroring reality ${ }^{19}$, pragmatism proposes treating knowledge dynamically. It wants creative intelligence to free human actions

\footnotetext{
210.

18 John Dewey, "Theories of Knowledge in Democracy and Education (1916)," in Ibid.,

19 The neo-pragmatist Rorty forwards that philosophy as a method has been concerned with mirroring nature. This strategy explains that philosophy, even if it consists of different methods such as conceptual analysis, phenomenological analysis, explication of meanings, logic of language, and the structure of the constituting activity of consciousness, is aiming at only one thing-to present things as they are. Its central concern is to be a general theory of representation: "To know is to represent accurately what is outside the mind; so to understand the possibility and nature of knowledge is to understand the way in which the mind is able to construct such representation." The result of this approach was the less philosophy had to do with the rest of culture and the more absurd its traditional pretensions seemed. This, for Rorty, is something deplorable, which is why he celebrates the thinkers like Wittgenstein, Heidegger, and Dewey whose works abandoned this approach: "they brought us to a period of 'revolutionary philosophy' by introducing new maps of terrain (viz., of the whole panorama of
}

17 John Dewey, "The Need for a Recovery of Philosophy (1917)," in Pragmatism: A Reader, 206-208. 


\section{0}

THE COPERNICAN REVOLUTION IN PRAGMATISM?

from a mechanically instrumental character-in the same way that it attempts to release us from the foundational clutches of craving for a supreme Reality. The pragmatic lesson is to liberate and liberalize action and free experience from routine and caprice through knowledge that perceives the interconnections between ideas, circumstances and experiences, and determines applicability in given situations. For Dewey, "knowledge" then is instrumental, for it is a means toward a projected goal or solution in a given situation. Its attitude is played both through anticipation and prediction, which are of equal weight in the process of acting itself:

But the purport of our discussion has been in praise of tools, instrumentalities, and means, putting them on a level equal in value to ends and consequences, since without them the latter are merely accidental, sporadic and unstable. To call known objects, in their capacity of being objects of knowledge, means is to appreciate them, not to depreciate them. ${ }^{20}$

What this means is that knowledge is not the end, but rather the tool of a possible goal. It does not pertain only to a definition of an object, but the different possibilities for its application. The theory of action in Dewey's pragmatism shows that an inquiry effects an existential transformation of subject matters inquired into, as knowledge brings about a change in the thing known. This is its cardinal doctrine. ${ }^{21}$ This implies that things have a transformative relevance as they exist for man's utilization-they are not predetermined for one purpose or are not cornered into a rigid definition, but their very existence paves the way for further discoveries. Dewey admits that this explanation is an effect of the experimental method treated as a scientific resource. Applied in reinventing philosophical thinking, it offers a systematized means of making knowledge, though as old as life, as a practical device. It can "aid in outlawing the literary, dialectic, and authoritative methods of forming beliefs which have governed the schools of the past" 22 and transfer their prestige to methods which will procure an active concern with things and persons.

The discussion shows that pragmatism is a practical philosophy: the problem of the possibility of knowledge is but an aspect of the question of the

human activities) which simply do not include those features which previously seemed to dominate." Wittgenstein deconstructed captivating pictures; Heidegger supplemented this with the historical awareness of mirror-imagery by letting men "distance" themselves from tradition; and Dewey wrote his polemics against traditional mirror-imagery out of a vision of a new kind of society, and not the ideal of objective cognition but that of aesthetic enhancement. See Philosophy and the Mirror of Nature, 3-14.

${ }^{20}$ Dewey, The Quest for Certainty, 298-299. 1968), 198.

${ }^{21}$ H. S. Thayer, Meaning and Action: A Critical History of Pragmatism (Bobbs-Merrill,

${ }^{22}$ Dewey, Pragmatism: A Reader, 211. 
relation of knowing to acting, of theory to practice. ${ }^{23}$ The gargantuan task of liberating inquiry from fundamental philosophical notions is crucial in order to ensure that the sphere of action is not fossilized within the demands of theoretical rudiments. Thinking and acting have a relationship that must not be severed, and in this regard the options as to how life can be affected for better or worse must be open for discussion-for action and opportunity justify themselves only to the degree in which they render life more reasonable and increase its value. ${ }^{24}$ The improvement of existence is the purpose of this way of thinking and living, and it is up to man to recognize and act on this himself.

But this analysis does not denote that we are able to thwart, control or redirect our practical interests immediately, for the "value" of knowledgeable actions form and depend on our ideas, judgments, and beliefs. As human beings, we are naturally able to reason, anticipate and believe-but these capacities should be appropriated astutely. For Dewey, these expressions of our nature need guidance, which is possible only through knowledge. When they are informed by knowledge, they themselves constitute, in their directed activity, intelligence in operation. ${ }^{25}$ Knowledge affords the sole means by which this redirection can be effected. The problem of knowledge is the problem of discovery of methods for carrying on this enterprise of redirection. It is a problem that never ends, for it is always in process. The constant gain is not in approximation to universal solution but in betterment of methods and enrichment of objects experienced. ${ }^{26}$ Hence, what one gains from the experience of scrutinizing, identifying and discerning reality is the reconstruction of a life of progress. It is not a life that is marked with a final end, but one that continually extends and grows.

Dewey contends that philosophy has always claimed universality for itself. It will make its claim good only when it connects this universality with the formation of directive hypotheses instead of with a sweeping pretension to knowledge of universal Being. ${ }^{27}$ This means that instead of the preoccupation of engaging metaphysical problems devoid of tangible human concern, philosophy must put "action" in its locus. Dewey recognizes that philosophy is insufficient if it assumes a role of a self-sufficing purveyor of realitysomething which Kant and his followers espoused-for its relevance only reveals itself when we conceive of knowledge as a statement of action, that statement being necessary, moreover, to the successful ongoing of action. When philosophizing is freed from metaphysics, pragmatism can place itself the center of historical concern, which seems to be a better future than the present. As Rorty explains:

${ }^{23}$ Dewey, Philosophy and Civilization, 5.

${ }^{24}$ John Dewey, "The Development of American Pragmatism” in The Essential Dewey, Volume 1: Pragmatism, Education, Democracy, ed. by Larry A. Hickman, and Thomas M. Alexander (Indiana University Press, 1998), 12.

${ }^{25}$ Dewey, The Quest for Certainty, 299.

${ }^{26}$ Ibid., 296.

${ }^{27}$ Ibid., 310. 


\section{THE COPERNICAN REVOLUTION IN PRAGMATISM?}

If Philosophy disappears, something will have been lost which was central to Western intellectual life-just as something central was lost when religious institutions were weeded out from among the intellectually respectable candidates for Philosophical articulation. But the Enlightenment thought, rightly, that what would succeed religion will be better. The pragmatist is betting that what succeeds the "scientific," positivist culture which the Enlightenment produced will be better. ${ }^{28}$

Consistent with this tenor is the very strong message forwarded by Dewey: that philosophic interpretations have altered the world, often as obstacles to intellectual progress. The real problem is how to alter the world for the better. ${ }^{29}$ This implies that both philosophy and science take part in the emendation of the world. As to how they can have a productive relationship in changing the world is thus the challenge that pragmatism undertakes.

\section{Science, Philosophy, and Pragmatism}

Sure enough, science has been the handmaiden of progress. When nature and method of knowledge are fairly understood, then interest must transfer itself from the possibility of knowledge to the possibility of its application to life. ${ }^{30}$ Men have basic needs that as much as possible have to be fulfilled in the best and most efficient ways; accordingly, science and technology provide the avenue for such fulfillment.

But while capitalizing on science is in itself natural and progressdriven, the application begs for a goal which complements and improves, rather than destroys the advancements in human life. Science should not be regarded as an end-in-itself, for one cannot just discover for the sake of discovering as the interwoven reality of the world cannot contain the effects and repercussions of an experiment or a breakthrough within a laboratory. Dewey suggests that a vision for science should be formed:

The need for direction of action in large social fields is the source of a genuine demand for unification of scientific conclusions. The astronomer, biologist, chemist, may attain systematic wholes, at least for a time, within his own field. But when we come to the bearing

28 Rorty, Consequences of Pragmatism, xxxviii. "Philosophy," as capitalized, refers to Plato's and Kant's lead of asking questions about certain normative notions (e.g., "truth," "rationality," "goodness") in the hope of better obeying such norms. The idea is to believe more truths or do more good or be more rational by knowing more about the Truth or Goodness or Rationality.

29 Thayer, Meaning and Action, 198.

${ }^{30}$ Dewey, The Essential Dewey, 20. 
of special conclusions upon the conduct of social life, we are, outside of technical fields, at a loss. The force of tradition and dogmatic authority is due, more than to anything else, to precisely this defect. Man has never had such a varied body of knowledge in his possession before, and probably never before has he been so uncertain and so perplexed as to what his knowledge means, what it points to in action and in consequences. ${ }^{31}$

Furthermore, original purposes and individual goals are subject to change and are privy to interests and agendas. The existence of the scientific attitude and spirit, even upon within a limited scale, is proof that science is capable of developing a distinctive type of disposition and purpose: a type that goes far beyond provision of more effective means for realizing desires which exist independently of any effect of science. ${ }^{32}$ It is already possible that successes in science can push men to create new desires and new ends, independent of the purpose originally set in the first place. There is a danger in this scene, as one can fall victim to making uninformed goals and decisions devoid of ethical considerations and a goal that aims for human betterment, and not annihilation.

For Dewey, philosophy can respond to the critical need of providing a vision for science. Its presence can help rein possible changes, and ensure that the values and ends of technological efforts are clear as to how it affects human life. Methodically, what philosophy learns from science is that its methods can help shape ethical and political thinking-that philosophic thinking can pattern itself on scientific inquiry not in terms of settling with final conclusions but as regards to means, ends and attitudes. The received view of Dewey's moral and political philosophy emphasizes its focus on the application of the 'scientific method' or 'crucial intelligence' to social, political, educational and economic problems ${ }^{33}$ - but as presented in this paper, this role is inspired not in the search for an unadulterable body of knowledge, but as a way of living and interacting in a continually developing world. This description shows how pragmatism is able to step up to the plate demanded to such needs:

A philosophy which abandoned its guardianship of fixed realities, values and ideals, would find a new career for itself. The meaning of science in terms of science, in terms of knowledge of the actual, may well be left to science itself. Its meaning in terms of the great human uses to which it may be put, its meaning in the service of

${ }^{31}$ Dewey, The Quest for Certainty, 312-313.

32 Dewey, The Essential Dewey, 56-57.

33 Matthew Festenstein, Pragmatism and Political Theory: From Dewey to Rorty (Chicago University Press, 1999), 19. 


\section{THE COPERNICAN REVOLUTION IN PRAGMATISM?}

possibilities of secure value, offers a field for exploration which cries out from very emptiness. ${ }^{34}$

Because pragmatism promotes purposeful knowledge and directed conduct in the organization of life, it then incorporates the search for progressive values that can be secured by humanity as the basis of its mapping of the future as impacted by science. In the same way we use the necessary methods of close observation and well-founded experimentation in the natural sciences, they can be applicable to the way we think when we talk about social affairs. This is the pragmatic approach that philosophy can take as a challenge that can alter the intellectual tradition:

It has to search out and disclose the obstructions; to criticize the habits of mind which stand in the way; to focus reflection upon needs congruous to present life; to interpret the conclusions of science with respect to their consequences for our beliefs about purposes and values in all phases of life. The development of a system of thought capable of giving this service is a difficult undertaking; it can proceed only slowly and through cooperative effort. ${ }^{35}$

Under such specifications, philosophy is not opposed to science; in fact, it uses the methods of the latter to reform and learn the ways of interaction. Dewey agues that in this position, philosophy serves as a mediator between the scientific conclusions and the different modes of social and personal action. Its critical mind would be directed against the domination exercised by prejudice, narrow interest, routine custom and the authority which issues from institutions apart from the human ends they serve. ${ }^{36}$ As attainable possibilities are projected and striven for in science, philosophy should then be there to formulate ideas on the implications of scientific discoveries as well as to direct science toward its future endeavors, with a specific emphasis on its humane impact. ${ }^{37}$ It is precisely because one will attain new knowledge from science that philosophy should be a guiding force. It is responsible for promoting a sense of confidence that one can control conduct based on the well-established judgment of values shared in solidarity. Pragmatism is relevant

${ }^{34}$ Dewey, The Quest for Certainty, 311.

35 Ibid., 313.

36 Ibid., 311

37 An example of bridging philosophy and science is seen in Habermas' attempt to direct us to question the impact of liberal eugenics, which is not a far-off future given the successes of biotechnology. He philosophically approaches the problem of how man is to be understood in the posttraditional stage of moral awareness: If we assume the position of "partner in evolution" and "play God" through genetic advancement, do we necessarily change our self-understanding in such a way that we may no longer see ourselves as ethically free and morally equal beings guided by norms and reasons? See The Future of Human Nature. 
in this sense, given that the relationship between theory and action is prioritized in its scheme.

Philosophy has ideally aimed for integrating knowledge completely. But knowledge, as attested by the nature of scientific inquiry and discovery, is ever-changing. Although one can attain eventual conclusions, syntheses, and generalizations, new problems and inquiries prop up for consideration. This is exactly what pragmatism recognizes and vehemently argues as true: the "diversification of discoveries and the opening up of new points of view and new methods are inherent in the progress of knowledge. The sheer increase of specialized knowledge will never work the miracle of producing an intellectual whole." 38 For this reason, philosophy will make sense and will only be relevant in human affairs-specially as regards to science-only if it entertains the relationship between a dynamic theory and an ever-changing context of human action.

Dewey is not unreasonable so as to say that pragmatism can solve all problems presented to man, for he is satisfied with describing philosophy as a vision, imagination, and reflection-with the caveat that these functions, apart from action, modify nothing and hence resolve nothing. But in a complicated and perverse world, action which is not informed by vision, imagination and reflection, is more likely to increase confusion and conflict rather than to straighten things out. ${ }^{39}$ Thus Dewey places his faith on pragmatism as a way for philosophy to assume this role as the steward of science. It tries to overhaul the previous preoccupation of a theoretical philosophy that simply presents reality and shifts it to one that utilizes knowledge in a future-oriented manner. In linking together theory and practice, Dewey's pragmatism is a brave endeavor to effect a Copernican revolution in the relationship between philosophy and science.

\section{Conclusion: The Copernican Revolution of Pragmatism}

Dewey is clear in stating that "philosophy is a method, and not an original fountainhead of truth, nor an ultimate standard of reference." 40 Philosophy's time of serving as the queen of the sciences and the articulator of universal principles has eclipsed. Its value runs not on defining or categorizing reality, but in interpreting and enriching life as a work in progress. It is the office of a man who is not only concerned with the present, but with the future as well. It is in pragmatic philosophy that the individual is brought to prominence, as he is the carrier of creative thought, the author of action and of its application. ${ }^{41}$ This individual is one who is aware of the interconnections of

\footnotetext{
${ }^{38}$ Dewey, The Quest for Certainty, 312.

${ }^{39}$ Dewey, "The Need for a Recovery of Philosophy (1917)" in Pragmatism: A Reader, 229-230.

40 Dewey, "The Significance of the Problem of Knowledge" in Philosophy and Civilization, 22.

${ }^{41}$ Dewey, "The Development of American Pragmatism" in The Essential Dewey, 12.
} 


\section{THE COPERNICAN REVOLUTION IN PRAGMATISM?}

things in the world, and developmentally bridges his thoughts and actions to ensure that his vision of a better world is at hand.

Thus, the Copernican revolution of pragmatism is the explicit attempt to redefine the future of philosophy. It provokes us to take away the conviction that philosophy is the search for a supreme reality; but even more than this, it redefines its role from a purveyor of reality to an active participant who is willing to utilize his knowledge of the world in virtue of problemsolving and continuity. If Kant's version of this revolution regarded the knowing mind as center in philosophy and effected separation of theory and human action, the Deweyan pragmatism's Copernican renovation transforms the relationship between thought and action as well as knowledge and progress. In pragmatic philosophy, there is a remarriage of systems of thought that were previously divorced. It links together theory and action; specifically, it makes science and philosophy work hand in hand based on its direction, purpose and impact on social life. Though it will take time and cooperation to establish the relational continuity of philosophy and science, Dewey sees a light at the end of the tunnel in this regard if we are able to creatively engage what we know and what we do:

Faith in the power of intelligence to imagine a future which is the projection of the desirable in the present, and to invent the instrumentalities of its realization, is our salvation. And it is faith which must be nurtured and made articulate: surely a sufficiently large task for our philosophy. ${ }^{42}$

As to whether Dewey's pragmatism deserves the title of a new "Copernican Revolution" in philosophy-which Kant so powerfully invoked as his legacy-it cannot be sufficiently answered, for philosophical undertakings in the present traverse many fields and views which are neither necessarily provoked nor inspired by Dewey. But what is clear is that his contribution to philosophy promotes the hope that it will be ushered to a new direction, and in this regard he is successful-and this lives on in the contemporary works of American and Continental thinkers such as Richard Rorty, Hilary Putnam and even Jürgen Habermas, whose practical, political and ethical interests dominate and engage their readers.

The Graduate School, University of Santo Tomas, Philippines

\section{References}

Dewey, John, Philosophy and Civilization (New York: Capricorn Books, 1963).

42 Dewey, “The Need for a Recovery of Philosophy (1917)” in Pragmatism: A Reader, 
The Quest for Certainty: A Study of the Relation of Knowledge and Action (New York: G.P. Putnam, 1960).

The Essential Dewey, Volume 1: Pragmatism, Education, Democracy, ed. by Larry A. Hickman and Thomas M. Alexander (Indiana University Press, 1998).

The Political Writings (Cambridge: Hackett, 1993).

Festenstein, Matthew, Pragmatism and Political Theory: From Dewey to Rorty (Chicago University Press, 1999).

Habermas, Jürgen, Knowledge and Human Interests, (USA: Beacon Press, 1972). The Future of Human Nature (Polity, 2003).

Kant, Immanuel, Critique of Pure Reason, ed. and trans. by Paul Guyer and Allen Wood (Cambridge University Press, 1999).

Menand, Louis ed., Pragmatism: A Reader (Vintage, 1997).

Niznik, Jozef and John Sanders eds., Debating the State of Philosophy: Habermas, Rorty, and Kolakowski (Westport, CT: Praeger, 1996).

Rorty, Richard, Philosophy and the Mirror of Nature-Thirtieth-Anniversary Edition (Princeton University Press, 2009).

Consequences of Pragmatism (Minneapolis: University of Minnesota Press, 1982).

Thayer, H.S., Meaning and Action: A Critical History of Pragmatism (Bobbs-Merrill, 1968).

White, Stephen K. ed., The Cambridge Companion to Habermas (Cambridge University Press, 1995). 